\title{
Polyvalent pneumococcal polysaccharide vaccines
}

\author{
M. R. Hilleman, ${ }^{1}$ A. A. McLean, ${ }^{2}$ \\ P. P. Vella,${ }^{3}$ R. E. Weibel, ${ }^{4} \&$ \\ A. F. WOODHOUR ${ }^{5}$
}

\begin{abstract}
A 14-valent pneumococcal vaccine has recently been licensed for general use after extensive testing in human subjects. Antibody production was satisfactory in $92 \%$ of individuals and a highly significant (76-92\%) reduction was found in the rates for pneumococcal pneumonias caused by the capsular types present in the vaccine. Children over 2 years of age respond well to the vaccine, but younger children may not respond satisfactorily to some capsular types. In adults, the duration of the protective effect is at present unknown, but no substantial booster response was seen after a second dose at 1 year. Such a booster dose, in fact, induced a marked increase in the degree of local reaction at the injection site.
\end{abstract}

The continued extreme importance of pneumococcal infections as a leading cause of death ${ }^{a}$ and the fact that a substantial proportion of persons succumb to the infection in spite of effective antimicrobial therapy ${ }^{b}$ have renewed interest in preventing pneumococcal disease by use of vaccines. The importance of prevention has been further emphasized by the appearance in recent months of types 57 and 6, pneumococcal strains from South Africa ${ }^{c}$ that have multiple or partial resistance to the antibiotics used to combat these infections.

Studies in the contemporary period by Dr Robert Austrian and his colleagues $b, d$ have abundantly confirmed the ability of polyvalent pneumococcal vaccines to elicit homologous antibody responses in man and to prevent illnesses caused by the homologous capsular types included in the vaccine.

Polyvalent pneumococcal capsular polysaccharide vaccines have been prepared in our laboratories using polysaccharides prepared by Dr Thomas Stoudt. These vaccines have USA.

${ }^{1}$ Director, Virus \& Cell Biology Research, Merck Institute for Therapeutic Research, West Point, PA 19486, USA.

2 Director, Biologics Evaluation \& Analysis, Merck Institute for Therapeutic Research, West Point, PA 19486,

${ }^{3}$ Sr. Investigator, Virus \& Cell Biology Research, Merck Institute for Therapeutic Research, West Point, PA 19486, USA.

- Director, Division of Preventive Medicine, Department of Pediatrics, University of Pennsylvania School of Medicine, Philadelphia, PA 19104, USA.

${ }^{5}$ Sr. Director/Asst. Area Head, Virus \& Cell Biology Research, Merck Institute for Therapeutic Research, West Point, PA 19486, USA.

${ }^{a}$ World health statistics annual, Vol. 1, Vital Statistics and Causes of Death. Geneva, World Health Organization, 1976.

$b$ Austrian, R. Vaccines of pneumococcal capsular polysaccharides and the prevention of pneumococcal pneumonia. In: Beers, R. F., Jr \& Bassett, E. G., ed., The role of immunological factors in infectious, allergic, and autoimmune processes, New York, Raven Press, 1976, pp. 79-89.

$c$ Morbidity and mortality weekly report, 26 (35): 285-286 (1977).

$d$ Austrian, R. ET AL. Prevention of pneumococcal pneumonia by vaccination. Transactions of the Association of American Physicians, 89: 184-194 (1976). 
Table 1. Antibody responses in 26 adults one month following a single dose of polyvalent (14-type pneumococcal vaccine) (50 $\mu \mathrm{g}$ of each capsular type, per dose)

\begin{tabular}{|c|c|c|c|}
\hline $\begin{array}{c}\text { Capsular } \\
\text { type }\end{array}$ & $\begin{array}{c}\text { Percentage } \\
\text { with 2-fold } \\
\text { or greater } \\
\text { increase in } \\
\text { antibody }\end{array}$ & $\begin{array}{c}\text { Final } a \\
\text { geometric } \\
\text { mean titre } \\
\text { (ng antibody } \\
\mathrm{N} / \mathrm{ml} \text { ) }\end{array}$ & $\begin{array}{c}\text { Mean increase } \\
(X \text {-fold })\end{array}$ \\
\hline 1 & 100 & 4050 & 16.9 \\
\hline 2 & 100 & 5148 & 10.7 \\
\hline 3 & 96 & 3556 & 8.1 \\
\hline 4 & 100 & 13931 & 9.1 \\
\hline 6 & 100 & 2456 & 13.6 \\
\hline 8 & 100 & 5761 & 13.8 \\
\hline 9 & 100 & 4132 & 11.0 \\
\hline 12 & 100 & 2470 & 15.9 \\
\hline 14 & 100 & 2488 & 8.3 \\
\hline 19 & 100 & 2540 & 8.5 \\
\hline 23 & 92 & 16785 & 6.5 \\
\hline 25 & 100 & 3295 & 24.0 \\
\hline 51 & 100 & 2396 & 12.9 \\
\hline 56 & 96 & 15528 & 7.0 \\
\hline
\end{tabular}

$a$ Initial mean titres ranged from 137 to $2580 \mathrm{ng}$ antibody $\mathrm{N} / \mathrm{ml}$.
Table 2. Protective efficacy of 6- and 12-valent pneumococcal vaccines for preventing verified pneumococcal pneumonia in gold miners, South Africa

\begin{tabular}{|c|c|c|c|c|c|}
\hline $\begin{array}{l}\text { Study } \\
\text { No. }\end{array}$ & $\begin{array}{l}\text { Vaccine } \\
\text { group }\end{array}$ & $\begin{array}{l}\text { No. of } \\
\text { cases } a / \\
\text { total }\end{array}$ & $\begin{array}{l}\text { Rate per } \\
1000\end{array}$ & Efficacy & $P$ \\
\hline \multirow{3}{*}{$\begin{array}{c}315 \\
(6- \\
\text { Valent) }\end{array}$} & Pneumococcal & $9 / 983$ & 9.2 & $76 \%$ & $<0.001$ \\
\hline & $\begin{array}{c}\text { (types 1, 2, 4, 8, } \\
12,25)\end{array}$ & & & & \\
\hline & Control $b$ & $78 / 2036$ & 38.3 & & \\
\hline \multirow{3}{*}{$\begin{array}{c}315 A \\
\text { (12- } \\
\text { Valent) }\end{array}$} & Pneumococcal & $1 / 540$ & 1.8 & $92 \%$ & $<0.004$ \\
\hline & $\begin{array}{l}\text { (types 1, 2, 3, 4, } \\
6,8,9,12,25, \\
51,56,73)\end{array}$ & & & & \\
\hline & Control $b$ & $25 / 1135$ & 22.0 & & \\
\hline
\end{tabular}

$a$ All cases, 14 or more days after vaccine was given.

$b$ The controls received either meningococcal vaccine or placebo in approximately equal numbers.

Table 3. Initial and revaccination antibody responses in infants given 12-valent pneumococcal vaccine

\begin{tabular}{|c|c|c|c|c|c|c|c|c|}
\hline \multirow[b]{2}{*}{$\begin{array}{l}\text { Capsular } \\
\text { type } a\end{array}$} & \multicolumn{4}{|c|}{ Infants 3-5 months of age ( 9 children) } & \multicolumn{4}{|c|}{ Infants 3 months of age ( 31 children) } \\
\hline & $\begin{array}{c}\text { Blood } \\
\text { sample } \\
\text { (time, } \\
\text { months) }\end{array}$ & $\begin{array}{l}\text { Percentage } \\
\text { with 2-fold } \\
\text { or greater } \\
\text { increase }\end{array}$ & $\begin{array}{c}\text { Geometric } \\
\text { mean titre } \\
\text { (ng antibody } \\
\mathrm{N} / \mathrm{ml})\end{array}$ & $\begin{array}{l}\text { Mean } \\
\text { increase } \\
(X-\text { fold })\end{array}$ & $\begin{array}{c}\text { Blood } \\
\text { sample } \\
\text { (time, } \\
\text { months) }\end{array}$ & $\begin{array}{l}\text { Percentage } \\
\text { with } 2 \text {-fold } \\
\text { or greater } \\
\text { increase }\end{array}$ & $\begin{array}{c}\text { Geometric } \\
\text { mean titre } \\
\text { (ng antibody } \\
\mathrm{N} / \mathrm{ml})\end{array}$ & $\begin{array}{l}\text { Mean } \\
\text { increase } \\
\text { (X-fold) }\end{array}$ \\
\hline \multirow[t]{4}{*}{8} & $0^{b}$ & & 76 & & $-b$ & & & \\
\hline & 1 & 100 & 881 & 11.6 & - & & & \\
\hline & $6 b$ & 80 & 357 & 4.7 & $21 b$ & & 236 & \\
\hline & 7 & 100 & 867 & 11.4 & 22 & $97 \%$ & 2980 & 12.6 \\
\hline \multirow[t]{4}{*}{1} & $0^{b}$ & & 32 & & $-b$ & & & \\
\hline & 1 & 50 & 63 & 2.0 & - & & & \\
\hline & $6^{b}$ & 13 & 42 & 1.3 & $21 b$ & $97 \%$ & 110 & \\
\hline & 7 & 75 & 118 & 3.7 & 22 & & 1014 & 9.2 \\
\hline \multirow[t]{4}{*}{12} & $0^{b}$ & & 14 & & $-b$ & & & \\
\hline & 1 & 14 & 14 & 1.0 & - & & & \\
\hline & $6^{b}$ & 45 & 22 & 1.6 & $21^{b}$ & $93 \%$ & 48 & \\
\hline & 7 & 45 & 24 & 1.7 & 22 & & 317 & 6.6 \\
\hline
\end{tabular}

$a$ The responses to type 8 were typical of types 3,8 and 9 . The responses to type 1 were typical of types $1,19,51$ and 56 . The responses to type 12 were typical of types 6,12 and 14. Serological data were not obtained for 2 of the types.

$b$ Times when first and second doses of vaccine were given. 
Table 4. Initial and revaccination antibody responses in 7 adults given 12-valent pneumococcal vaccine ${ }^{a}$

\begin{tabular}{ccccc}
\hline $\begin{array}{c}\text { Capsular } \\
\text { type }\end{array}$ & $\begin{array}{c}\text { Blood } \\
\text { sample } \\
\text { (time, } \\
\text { months) }\end{array}$ & $\begin{array}{c}\text { Percentage } \\
\text { with 2-fold } \\
\text { or greater } \\
\text { increase }\end{array}$ & $\begin{array}{c}\text { Geometric } \\
\text { mean titre } \\
\text { (ng antibody } \\
\text { N/ml) }\end{array}$ & $\begin{array}{c}\text { Mean } \\
\text { increase } \\
\text { (X-times) }\end{array}$ \\
\hline 8 & $0^{b}$ & 100 & 5868 & 12.1 \\
& 1 & 100 & 6741 & 13.9 \\
1 & $13^{b}$ & 100 & 7197 & 14.8 \\
& 14 & 100 & 412 & \\
& $0^{b}$ & 1 & 1419 & 3.4 \\
& $13^{b}$ & 100 & 2167 & 5.3 \\
& $14^{b}$ & 100 & 2506 & 6.1 \\
& $0^{b}$ & & 372 & \\
& 1 & 100 & 2377 & 6.4 \\
& $13^{b}$ & 86 & 2046 & 5.5 \\
& $14^{b}$ & 86 & 2201 & 5.9 \\
& & & &
\end{tabular}

$a_{50 \mu \mathrm{g}}$ of each pneumococcal capsular polysaccharide was included in the vaccine.

$b$ Times when the first and second doses of vaccine were given.

been studied extensively in $\operatorname{man} .^{a, b}, c$ All these investigations were carried out under the Investigational New Drug regulations of the US Public Health Service in accordance with accepted ethical standards and free and informed consent. Table 1 shows the typical antibody response in human adults to a 14-valent pneumococcal vaccine. At least $92 \%$ of the individuals developed antibody against each polysaccharide and the mean increase in antibody level ranged from 6.5to 24-fold.

Tests to measure protective efficacy of 6- and 12-valent pneumococcal polysaccharide vaccines were carried out in collaboration with Dr Pieter Smit and his associates ${ }^{b}$ in gold miners in South Africa. Table 2 shows that the vaccines effected a 76-92\% reduction in the rates for pneumococcal pneumonias caused by the same capsular types present in the vaccines. These reductions are highly significant, statistically.

Children 2 years of age and older generally respond well to the vaccine, but younger children may not respond satisfactorily to some of the capsular types. Table 3 shows the

a WeIBeL, R. E. ET AL. Studies in human subjects of polyvalent pneumococcal vaccines. Proceedings of the Society for Experimental Biology and Medicine, 156: 144-150 (1977).

$b$ SMIT, P. ET AL. Protective efficacy of pneumococcal polysaccharide vaccines against pneumococcal pneumonia. Journal of the American Medical Association, 238: 2613-2616 (1977).

$c$ BoRgoño, J. M. ET AL. Vaccination and revaccination with polyvalent pneumococcal polysaccharide vaccines in adults and infants. Proceedings of the Society for Experimental Biology and Medicine, 157: 148-154 (1978). 
very great differences in antibody responses among infants 3-5 months of age given a single dose of 12-valent vaccine in tests carried out in collaboration with Dr Manuel Borgoño and his colleagues. ${ }^{a}$ Roughly one-third of the children responded well to 3 capsular types as shown for type 8; one-third responded moderately to 4 capsular types as shown for type 1 ; and one-third responded poorly to 3 capsular types as shown for type 12 . The antibodies tended to decline rapidly after the first dose of vaccine and a second dose of the same vaccine given 6 months later did little more than return the titres to the original onemonth postvaccination levels. Revaccination was most effective (Table 3) when a second dose of vaccine was given 18 months after the first. Nearly all the children (93-97\%) responded to the vaccine and the mean increase in titre was 6.6-12.6-fold.

The duration of the protective effect of pneumococcal capsular polysaccharide vaccines is at present unknown, but it has been shown in previous studies ${ }^{b}, c$ with different pneumococcal vaccines that antibody induced by the vaccine was present at one-fifth to one-half or more of its peak values 2 or 3 years after a single injection. Abundant residual antibody persisted in some individuals for 8 years after vaccination. Table 4 shows the initial and revaccination antibody responses against three pneumococcal capsular types in 7 adults given 12-valent pneumococcal polysaccharide vaccine. There was only a slight decline in antibody 1 year after the initial vaccine dose, and there was no substantial booster response when a second dose of vaccine was administered at that time. Importantly, however, following the booster vaccination there was a marked increase in the degree of local reaction at the injection site that was characterized mainly by erythema and induration. This was "Arthus-like" and may have been due to local antigen-antibody union at the injection site. Table 5, in support of this contention, shows a correlation between the degree of reaction and the amount of anti-pneumococcal circulating antibody at the time of vaccination. Obviously, there was no advantage in revaccinating adults at 1 year and the time at which revaccination can induce a useful increase in antibody titre remains to be determined.

Pneumococcal vaccine, 14-valent, has recently been licensed for general use, and distribution of the vaccine has been initiated in the USA.

$a$ Borgoño, J. M. ET AL. Vaccination and revaccination with polyvalent pneumococcal polysaccharide, vaccines in adults and infants. Proceedings of the Society for Experimental Biology and Medicine, 157: 148-154. (1978).

$b$ AUSTRIAN, R. Vaccines of pneumococcal capsular polysaccharides and the prevention of pneumococcal pneumonia. In: Beers, R. F., Jr \& Bassett, E. G., ed. The role of immunological factors in infectious, allergic, and autoimmune processes, New York, Raven Press, 1976, pp. 79-89.

$c$ Heidelberger, M. Persistence of antibodies in man after immunization. In: Pappenheimer, A. J., Jr, ed. The nature and significance of the antibody response, New York, Columbia University Press, 1953, Ch. 5, pp. 90-101

\section{RÉSUME}

\section{Efficacité des vaccins polyosidiques polyvalents antipneumococciques}

Les infections à pneumocoques continuent à provoquer une mortalité importante en dépit des ressources thérapeutiques disponibles et ce fait, joint à la propagation récente à partir de l'Afrique du Sud de souches présentant une résistance partielle ou multiple aux antibiotiques, explique le regain d'intérêt manifesté pour la prévention de la pneumonie par la vaccination.

Les études contemporaines ont confirmé que les vaccins polyvalents antipneumococciques suscitaient chez l'homme la formation d'anticorps homologues des types capsulaires contenus dans le 
vaccin. Une série d'essais ont été effectués sur plusieurs groupes de population (adultes, enfants et nourrissons). Les résultats, illustrés par 6 tableaux, peuvent se résumer comme suit:

Chez $92 \%$ au moins des adultes vaccinés, le titre d'anticorps contre chacun des 14 polyosides contenus dans le vaccin a augmenté en moyenne de 6,5 à 24 fois (tableau 1).

L'essai visant à évaluer le degré de protection conféré par des vaccins polyvalents contenant 6 et 12 types de polyosides respectivement a fait apparaître une réduction de 76 à $92 \%$ des cas de pneumonie causés par les types capsulaires correspondants dans le groupe d'adultes vacciné comparé à un groupe témoin (tableau 2).

Chez des nourrissons ayant reçu une dose unique de vaccin contenant 12 types de polyosides, la réponse immunitaire a été très variable selon le type capsulaire éprouvé. Le titre d'anticorps a rapidement diminué après la primovaccination, et une seconde dose administrée 6 mois plus tard a permis de le faire remonter à un niveau ne dépassant pas sensiblement celui atteint 1 mois après la première vaccination. De meilleurs résultats ont été obtenus dans un groupe revacciné 18 mois après avoir reçu la première dose, avec un titre d'anticorps multiplié par 6,6 à 12,6 chez 93-97\% des enfants (tableau 3).

La durée de la protection est mal connue. Selon des études antérieures, elle paraît pouvoir s'étendre jusqu'à 8 ans, mais les titres d'anticorps diminuent substantiellement dès la deuxième ou la troisième année suivant la vaccination. L'administration d'une seconde dose à un groupe d'adultes 1 an après la première n'a pas accru la réponse de manière très sensible (tableau 4), mais elle a provoqué une réaction beaucoup plus marquée (du type Arthus) au point d'injection. Le tableau 5 fait ressortir une corrélation entre l'intensité de cette réaction et le taux d'anticorps antipneumococciques circulants au moment de la vaccination, et on peut en déduire qu'elle résulte de la combinaison antigène/anticorps à l'endroit où est pratiquée l'injection de vaccin.

L'emploi en pratique courante du vaccin contenant 14 types de polyosides a été récemment officiellement autorisé aux Etats-Unis d'Amérique. 